\title{
Natural Defense and Chemical Carcinogenesis
}

\author{
I. P. Witz ${ }^{1}$, M. Efrati ${ }^{1}$, R. Ehrlich ${ }^{1}$, B. Gonen ${ }^{1}$, L. Kachlon ${ }^{1}$, O. Sagi ${ }^{1}$, E. Sahar ${ }^{2}$, \\ L. Shochat ${ }^{1}$, N. I. Smorodinsky ${ }^{1}$, S. Yaakov ${ }^{1}$, M. Yaakubowicz ${ }^{1}$, and I. Yron
}

\section{A. Introduction}

It is becoming increasingly clear that chemical, physical, and biologic carcinogens are immunosuppressive. Most of the available information on the immunosuppressive activity of oncogenic agents concerns adaptive immunity [17]. Recent studies have indicated that exposure of laboratory animals to various carcinogenic insults affected also certain expressions of innate, natural immunity such as natural killer (NK) activity (for review see [2]).

In previous studies, we demonstrated that the chemical carcinogen dimethylbenzanthracene (DMBA) exerted a severe suppressive effect on NK activity of mouse splenocytes $[3,4]$. In the present study, we addressed the following questions:

1. Is the decrease in NK activity of DMBA-treated mice restricted to the spleen, or is this decrease also evident in other lymphocyte-containing compartments? To answer this question, we compared the NK activity of peripheral blood leukocytes (PBL) from untreated and DMBA-treated mice. We also performed adoptive transfer experiments in which we tested the NK activity of splenocytes from lethally irradiated recipients reconstituted with syngeneic bone marrow from either untreated or from DMBA-treated donors.

1 Departments of Microbiology

2 Biotechnology, The George S. Wise Faculty of Life Sciences, Tel Aviv University, Tel Aviv, Israel
2. Is the decrease in NK activity of DMBA-treated animals due to a functional defect or is it due to a reduction in the size of the NK cell population? This was answered in the present study by performing a flow cytometry analysis of cells expressing asialo-GM-1- (a ganglioside expressed on the membrane of certain lymphocyte subpopulations, especially NK cells [7]), in the spleen of DMBA-treated animals.

3. Are other cells of the immune system also affected by DMBA? We have begun to answer this by performing mixed lymphocyte reactions (MLR) in which lymphocytes of DMBA-treated animals served as responders.

4. Is the activity of natural antitumor antibodies (NATA) affected by carcinogen treatment? We have compared NATA activity of untreated mice with that of urethane- or DMBA-treated ones.

\section{B. Results}

I. The NK Activity of PBL from DMBATreated BALB/c Mice

Table 1 shows that the NK activity of PBL from DMBA-treated BALB/c mice is considerably lower than that of untreated ageand sex-matched syngeneic controls. These results indicate that the effect of DMBA on 
Table 1. The NK activity of PBL from DMBA-treated $\mathrm{BALB} / \mathrm{c}$ mice
Cytotoxicity index \pm standard deviation ${ }^{\mathrm{a}}$

\begin{tabular}{ccc}
\hline Effector : target & Untreated controls $^{\mathrm{b}}$ & DMBA-treated $^{\mathrm{c}}$ \\
\hline $100: 1$ & $10.0 \pm 4.6$ & $6.1 \pm 3.9$ \\
$50: 1$ & $7.4 \pm 5.1$ & $4.3 \pm 2.7$ \\
$25: 1$ & $4.9 \pm 4.0$ & $2.9 \pm 2.0$ \\
$12.5: 1$ & $3.4 \pm 2.8$ & $2.0 \pm 1.3$ \\
\hline
\end{tabular}

a Cytotoxicity index $=100 \times \frac{\mathrm{cpm} \text { released in experimental well }- \text { spontaneous release }}{\text { total } \mathrm{cpm} \text { incorporated }- \text { spontaneous release } \mathrm{cpm}}$

Mean cytotoxicity index \pm standard deviation given by PBL obtained from the tail vein from $30-50$ mice tested individually in 3 experiments. YAC-1 cells were used as targets

b 8 to 10 -week-old females

c Age and sex-matched mice were treated intragastrically with $1 \mathrm{mg}$ / week DMBA (Sigma) dissolved in corn oil; 4 weekly treatments were given; NK activity was tested 21 days after the last DMBA treatment

NK activity was systemic and not restricted to the spleen.

II. The NK Activity of Splenocytes from Lethally Irradiated BALB/c Mice

Reconstituted with Bone Marrow Cells from DMBA-Treated Donors

In this series of experiments, we assayed the ability of adoptively transferred bone marrow cells from DMBA-treated mice or from untreated controls to reconstitute splenic NK activity of syngeneic BALB/c mice irradiated with $950 \mathrm{rad}$. The results shown in Table 2 indicate that DMBA treatment, under the experimental conditions utilized in this study, impaired the ability of bone marrow precursors to reconstitute NK activity in lethally irradiated recipients.

In order to find out whether or not DMBA was selectively toxic toward lymphatic cells such as NK cells, we compared spleen colonies of irradiated mice which received an adoptive transfer of bone marrow cells either from DMBA-treated mice or from untreated controls. We detected no qualitative or quantitative differences between the two groups. DMBA also failed to affect the ability of bone marrow cells to produce colonies in soft agar. These results suggest that DMBA acts selectively on lymphocyte precursors in the bone marrow.

III. Flow Cytometry Analysis of Splenocytes from DMBA-Treated BALB/c Mice

The percentage of Thy-1, Lyt-1, Lyt-2, and asialo-GM-1-positive cells in the spleen of untreated or DMBA-treated animals was determined by flow cytometry using commercially available fluorescently tagged antibodies. The results presented in Table 3 indicate that the percentage of the total $\mathrm{T}$ cell population and the two major $T$ cell subpopulations were not affected by DMBA. The percentage of asialo-GM1-positive NK cells was however drastically reduced. It should be remembered that the size of the spleen in DMBA-treated mice was reduced by about $50 \%$ [4]. The absolute number of $\mathrm{T}$ cells in the spleen was therefore reduced by the same factor whereas that of asialo-GM-1-positive cells was reduced by a much larger factor. These results suggest that DMBA was selectively toxic toward asialo-GM-1-positive cells with NK activity. However, sorting of asialo GM-1 positive cells originating in spleens or PBL of control or DMBA-treated animals (results not shown) indicated that the decreased NK activity observed in the 
Table 2. The NK activity of splenocytes from lethally irradiated $\mathrm{BALB} / \mathrm{c}$ mice reconstituted with bone marrow cells from untreated or DMBA-treated donors
Table 3. Flow cytometry of splenocytes from DMBAtreated $\mathrm{BALB} / \mathrm{c}$ mice
Cytotoxicity index \pm standard deviation (\% of nonirradiated controls) ${ }^{a}$

Source of bone marrow cells ${ }^{b}$

Effector: target Untreated donors DMBA-treated

\begin{tabular}{rrrl}
\hline $100: 1$ & 78 & 45 \\
50 & $: 1$ & 81 & 51 \\
25 & $: 1$ & 84 & 58 \\
$12.5: 1$ & 85 & 52 \\
\hline
\end{tabular}

a See footnote a Table 1 . The NK activity of splenocytes from nonirradiated, untreated controls was taken as the $100 \%$ baseline. The values represent the percentage activity (given by the indicated group) of such controls. The cytotoxicity index given by the NK cells of the control group ranged from 14 at an effector: target ratio of $12.5: 1$ to 32 at an effector : target ratio of $100: 1$. Average values of 12 experiments

b 8 to 10 -week old female BALB/c mice were irradiated with $950 \mathrm{rad}$ and reconstituted intravenously the same day with $5 \times 10^{6}$ bone marrow cells either from donors treated with $6 \mathrm{mg} \mathrm{DMBA}(1 \mathrm{mg} /$ week see footnote ${ }^{c}$ Table 1$)$ or from age and sex-matched untreated donors. NK activity was assayed 1 month after irradiation and cell transfer. YAC-1 cells served as targets

\begin{tabular}{lcc}
\hline & \multicolumn{2}{l}{$\begin{array}{l}\text { Splenocytes from DMBA-treated mice } \\
\text { (\% of untreated controls) }\end{array}$} \\
\cline { 2 - 3 } Marker & $3 \mathrm{mg} \mathrm{DMBA}$ & $6 \mathrm{mg} \mathrm{DMBA}$ \\
\hline Thy-1 $^{\mathrm{d}}$ & $106 \pm 13(5)^{\mathrm{c}}$ & $97 \pm 8(5)^{\mathrm{c}}$ \\
Lyt-1 $^{\mathrm{d}}$ & $88 \pm 4(3)$ & $94 \pm 13(3)$ \\
Lyt-2 $^{\mathrm{d}}$ & $92 \pm 10(3)$ & $90 \pm 9(3)$ \\
Asialo-GM-1 $^{\mathrm{e}}$ & $48 \pm 18(3)$ & $41 \pm 30(3)$
\end{tabular}

a Splenocyte suspensions were freed of erythrocytes by osmotic shock and then passed through nylon wool columns. The nonadherent fraction was used

b The percentage of marker-positive cells in spleens of untreated controls was taken as the $100 \%$ baseline. Nonadherent splenocytes of such untreated controls contained $62 \%$ Thy-1-positive cells, $72 \%$ Lyt-1-positive cells, $21 \%$ Lyt-2-positive cells, and $4.4 \%$ asialo-GM1-positive cells

c Numbers in parentheses indicate the number of experiments performed. A pool of spleens from 3-4 mice was tested in each experiment. The mice were tested 2-4 weeks after the last DMBA treatment (see footnote ${ }^{c}$ to Table 1)

d Cells were directly stained with FITC-conjugated monoclonal antibody directed against the appropriate marker

- Cells were first treated with rabbit IgG directed against asialoGM-1 and then stained with FITC-conjugated affinity-purified goat antibody against rabbit IgG 
Table 4. The ability of splenocytes from DMBAtreated $\mathrm{BALB} / \mathrm{c}$ mice to respond to alloantigens ${ }^{a}$ in one-way mixed lymphocyte reactions

\begin{tabular}{lcc}
\hline Treatment & $\begin{array}{l}\text { Average } \\
\text { stimulation } \\
\text { index }\end{array}$ & $\begin{array}{l}\text { (\% of } \\
\text { untreated } \\
\text { controls) }\end{array}$ \\
\hline None & $24.5 \pm 13.3$ & 100 \\
$3 \mathrm{mg}$ DMBA & $11.1 \pm 7.4$ & 45 \\
6 mg DMBA & $9.6 \pm 6.3$ & 39 \\
None & $9.6 \pm 5.1$ & 100 \\
$\begin{array}{l}\text { Irradiation + adoptive transfer } \\
\quad \text { of bone marrow cells from }\end{array}$ & $3.6 \pm 1.3$ & 37 \\
$\quad$ untreated donors & & \\
$\begin{array}{l}\text { Irradiation + adoptive transfer } \\
\quad \text { of bone marrow cells from }\end{array}$ & $2.1 \pm 0.4$ & 22 \\
$\quad$ DMBA-treated donors & & \\
\hline
\end{tabular}

a $\mathrm{C} 3 \mathrm{H} / \mathrm{eB}$ cells $\left(\mathrm{H}-2^{\mathrm{k}}\right)$ served as stimulators. Stimulator cells were treated with mitomycine $\mathrm{C}$

b Stimulation index $=\frac{\mathrm{cpm} \text { in allogeneic MLR }}{\mathrm{cpm} \text { in syngeneic MLR }}$

An average of 8-12 experiments is presented

c For details see footnote ${ }^{\text {b }}$ Table 2 latter mice was due to a reduction in the size of the NK cell population rather than to a functional defect of these cells.

IV. The Ability of T Cells from DMBATreated BALB/c Mice to Respond in the Mixed Lymphocyte Reaction

As we have seen, the marker analysis of splenic $T$ cells of DMBA-treated mice showed no difference between the treated mice and untreated controls. We carried out experiments to find out whether DMBA, while not affecting the number of $T$ cell populations, had some effects on their responder function in MLR. The results of assays in which splenocytes from DMBA-treated or from untreated $\mathrm{BALB} / \mathrm{c}$ $\left(\mathrm{H}-2^{\mathrm{d}}\right)$ mice were allowed to react against $\mathrm{C} 3 \mathrm{H} / \mathrm{eB}\left(\mathrm{H}-2^{\mathrm{k}}\right)$ antigens, are given in Table 4. It was shown that DMBA administration reduced the ability of $\mathrm{BALB} / \mathrm{c}$ mice to respond to the assayed alloantigens by an average of $50 \%$.

Adoptive transfer experiments in which bone marrow from untreated or from DMBA-treated animals was transferred to lethally irradiated recipients were performed. The results of these experiments indicated (Table 4) that bone marrow precursors were also affected by DMBA in their capacity to reconstitute MLR responder activity.

\section{Lymphoma-Reactive Natural Anti- bodies in Untreated and in Carcinogen- Treated BALB/c Mice}

In a previous study [19] we found that sera from young normal $\mathrm{BALB} / \mathrm{c}$ mice contain IgM antibodies able to mediate complement-dependent lysis of certain syngeneic or allogeneic tumor target cells. The titer of such naturally occurring antitumor antibodies (NATA) was found to increase with aging.

A longitudinal serologic study comparing the cytotoxicity potential of NATA from normal and from urethane-treated BALB/c mice was performed. It was found that urethane-treated mice that did not develop primary lung adenomas within the duration of the experiment had significantly lower NATA titers against the L5178-Y lymphoma than urethane-treated animals that developed lung adenomas. This difference was evident in two independent experiments. The results suggested that the 
Table 5. The binding pattern of naturally occurring lymphoma-reactive antibodies

\begin{tabular}{|c|c|c|c|c|c|c|}
\hline & & \multicolumn{5}{|c|}{ Binding index of indicated monoclonal ${ }^{a}$} \\
\hline & & 1.67 & 1.80 & 3.88 & 2.2 & 1.91 \\
\hline Lymphomas & $\begin{array}{l}\text { L5178-Y } \\
\text { Eb } \\
\text { Esb } \\
\text { YAC-1 } \\
\text { RLơl }\end{array}$ & $\begin{array}{l}+++ \\
- \\
- \\
- \\
++\end{array}$ & $\begin{array}{l}+++ \\
- \\
- \\
+++ \\
+++\end{array}$ & $\begin{array}{l}++ \\
+++ \\
+++ \\
+++ \\
+++\end{array}$ & $\begin{array}{l}++ \\
- \\
- \\
+ \\
-\end{array}$ & $\begin{array}{l}++ \\
+++ \\
+++ \\
++ \\
+\end{array}$ \\
\hline Lymphatic cells & $\begin{array}{l}\text { Bone marrow } \\
\text { Thymocytes } \\
\text { Splenocytes } \\
\text { Peritoneal macrophages }\end{array}$ & $\begin{array}{l}+ \\
++ \\
+ \\
-\end{array}$ & $\begin{array}{l}+ \\
- \\
- \\
-\end{array}$ & $\begin{array}{l}+ \\
+ \\
+ \\
+\end{array}$ & $\begin{array}{l}+ \\
+ \\
- \\
-\end{array}$ & $\begin{array}{l}+ \\
+ \\
- \\
+\end{array}$ \\
\hline Nonlymphatic normal & $\begin{array}{l}\text { Embryonic fibroblasts } \\
\text { Erythrocytes (MRBC) } \\
\text { Bromelain-treated } \\
\text { MRBC }\end{array}$ & $\begin{array}{l}+++ \\
+ \\
++\end{array}$ & $\begin{array}{l}- \\
- \\
-\end{array}$ & $\begin{array}{l}+++ \\
- \\
++\end{array}$ & $\begin{array}{l}- \\
+ \\
+++\end{array}$ & $\begin{array}{l}- \\
+ \\
++\end{array}$ \\
\hline
\end{tabular}

a The binding pattern was established by calculating the binding index (BI). This is the ratio between the binding (cpm) to the indicated cell of the tested monoclonal and the nonspecific binding of the radioactive reagent. $+++\mathrm{BI}=>10 ;++\mathrm{BI}=5-10 ;+\mathrm{BI}=1.5-5 ;-\mathrm{BI}=<1.5$

lower antibody activity of the urethanetreated mice that did not develop tumors existed even before exposure to the carcinogenic insult. The results of preliminary experiments suggest that a similar situation also exists with DMBA carcinogenesis. These findings raise the possibility that certain populations could be segregated according to their natural antibody profile into those individuals which will develop primary tumors within a certain period if exposed to a subthreshold amount of carcinogen, and those which will not. Furthermore, the results indicated that these naturally occurring lymphoma-reactive antibodies may play a biologic role in the development of certain primary tumors.

In order to study these antibodies and the antigens they react with, we prepared hybridomas from lymphocytes of LPSstimulated, but otherwise untreated BALB/c mice. These hybridomas were screened for secretion of antibodies which bind to L5178-Y lymphoma cells. Some binding characteristics of five of the L5178-Y lymphoma-reactive natural monoclonals are given in Table 5. It can be seen that two of the five natural hybridomas secrete antibodies which bind primarily to lymphoid tissues.

\section{Discussion}

Natural defense mechanisms are considered by several investigators to be the first line of defense against developing neoplasia [10]. If this is indeed the case, then suppression of such defense mechanisms, for example by cancer-inducing agents, might enhance the proliferation and progression of transformed cells toward a fully fledged malignancy. There are numerous investigations showing that exposure to cancer-inducing agents such as chemicals [4], irradiation [8, 15], or hormones [12] causes a depression in one or more of the expressions of natural immunity.

The major part of the present study is an extension of previous findings, showing that the chemical carcinogen DMBA causes a severe suppression of NK activity shortly after administration and long before the appearance of palpable tumors [4]. In this study, we demonstrated that the effect is systemic and that bone marrow precursors are affected. The results also proved that the decreased NK activity was due to a selective toxic effect toward NK precursors and perhaps also to mature NK (asialoGM-1-positive cells), but not due to a functional defect of such cells. We do not 
know, as yet, if the NK deficiency of DMBA-treated mice contributes toward tumor development.

The mode of induction of naturally occurring-antibodies, their physiologic role, and the mechanisms regulating their levels and functions are largely unknown.

It seems that the repertoire of naturally occurring antibodies is rather large, equaling perhaps that of adaptively induced antibodies. Among the epitopes recognized by naturally occurring antibodies are many expressed on normal cells $[6,21]$, on malignant cells $[13,14]$, or on various oncoviruses $[9,16]$. None of these epitopes is restricted to these cells or viruses. However, even in this situation, naturally reacting antibodies directed against epitopes expressed on malignant cells could function as regulators of the progression of malignancy. This could occur at several levels by various mechanisms such as binding to and neutralization of oncogenic viruses $[1,11]$, opsonizing transformed or nascent malignant cells, lysing them by complement activation, or arming of naturally occurring $\mathrm{Fc}$ receptor-positive killer immunocytes [18, 20]. It is also possible that natural antibodies may enhance tumor growth and development by direct or indirect mechanisms [5]. Our previous studies suggested that certain lymphoma-reactive natural antibodies may play a role in chemical carcinogenesis.

The characterization of these antibodies is an essential prerequisite in order to establish the physiologic function of such antibodies and the role they play in controlling primary tumor development. Establishing hybridomas secreting tumor-reactive antibodies is the first step toward this goal.

Acknowledgments. This work was supported by a grant awarded by Concern Foundation in conjunction with the Cohen-Appelbaum-Feldman Families Cancer Research Fund, Los Angeles, California. Isaac P. Witz is the incumbent of the David Furman chair of Immunobiology of Cancer

\section{References}

1. Bentvelzen P, Creemers PC (1977) Natural immunity to murine mammary tumor viruses. Contemp Top Immunobiol 6:229
2. Ehrlich R, Witz IP (1982) Natural killer cells and naturally occuring antibodies as representatives of natural tumor immunity. Pathobiol Ann 12:85

3. Ehrlich R, Efrati M, Bar-Eyal A, Wollberg M, Schiby G, Ran M, Witz IP (1980) Natural cellular reactivities mediated by splenocytes from mice bearing three types of primary tumors. Int J Cancer 26:315

4. Ehrlich R, Efrati M, Malatzky E, Shochat L, Bar-Eyal A, Witz IP (1983). Natural host-defence during oncogenesis. NK activity and dimethylbenzanthracene carcinogenesis. Int J Cancer 31:67

5. Feldman JD (1972) Immunological enhancement: A study of blocking antibodies. Adv Immunol 15:167

6. Guilbert B, Dighiero G, Avrameas S (1982) Naturally occurring antibodies against nine common antigens in normal humans. 1. Detection, isolation and characterization. J Immunol 128:2779

7. Habu S, Okumura K (1982) Cell lineage of NK cells: Evidence for $\mathrm{T}$ cell lineage. In: Herberman RB (ed) NK cells and other natural effector cells. Academic, New York, p 209

8. Haller O, Wigzell H (1977) Suppression of natural killer activity with radioactive strontium: effector cells are marrow dependent. J Immunol 118: 1503

9. Hanna MG Jr, Ihle JN, Batzing BL, Tennant TW, Schenley CK (1975): Assessment of reactivities of natural antibodies to endogenous RNA tumor virus envelope antigens and virus-induced cell surface antigens. Cancer Res 35: 164

10. Herberman RB, Holden HT (1978) Natural cell mediated immunity. Adv Cancer Res 27:305

11. Thle JN, Aurthur LO, Fine DL (1976) Autogenous immunity to mouse mammary tumor virus in mouse strains of high and low mammary tumor incidence. Cancer Res 36: 2840

12. Kalland T (1980) Reduced natural killer activity in female mice of neonatal exposure to diethylstilbestrol. J Immunol 124: 1297

13. Martin SE, Martin WJ (1975) Anti-tumor antibodies in normal mouse sera. Int $\mathrm{J}$ Cancer 15:658

14. Menard S, Colnaghi MI, Della Porta G (1977) Natural antitumor serum reactivity in $\mathrm{BALB} / \mathrm{c}$ mice. I. Characterisation and interference with tumor growth. Int $J$ Cancer 19:267

15. Parkinson DR, Brightman RP, Waksal SD (1981) Altered natural killer cell biology in C57BL/6 mice after leukomogenic split-dose irradiation. J Immunol 126: 1460 
16. Snyder HW Jr, Fleissner E (1980) Specificity of human antibodies to oncovirus glycoproteins: Recognition of antigen by natural antibodies directed against carbohydrate structures. Proc Natl Acad Sci USA 77:1622

17. Stutman $O$ (1975) Immunodepression and cancer. Adv Cancer Res 22:261

18. Wakefield JD, Batchelor JR (1966) The effect of natural antibody in guinea pig serum on mouse lymphoma cells in vitro and in vivo. Immunology 11:441

19. Witz IP, Yaakubowicz M, Gelernter I, Hochberg Y, Anavi R, Ran M (1984) Studies on the level of natural antibodies reactive with various tumor cells during Urethane carcinogenesis in BALB/c mice. Immunobiology 166:131

20. Wolosin LB, Greenberg AH (1979) Murine natural anti-tumor antibodies. I. Rapid in vivo binding of natural antibody by tumor cells in syngeneic mice. Int J Cancer 23:519

21. Wolosin LB, Greenberg AH (1981) Genetics of natural antitumor antibody production: Antibodies to MHC-linked determinants detected in the serum of unstimulated mice. $\mathrm{J}$ Immunol 126: 1456 